\title{
Arthroscopic management of tibial eminence fracture: a review of treatment outcome
}

\author{
Shreekantha K. S., Gowthamapradhaban N.*, Deepak Malik, Mahendranath
}

Department of Orthopaedics, Sapthagiri Institute of Medical Sciences \& Research Centre, Bangalore, Karnataka, India

Received: 18 March 2021

Revised: 14 April 2021

Accepted: 15 April 2021

\section{*Correspondence: \\ Dr. Gowthamaprathaban N., \\ E-mail: prathaban92@rediffmail.com}

Copyright: ( $)$ the author(s), publisher and licensee Medip Academy. This is an open-access article distributed under the terms of the Creative Commons Attribution Non-Commercial License, which permits unrestricted non-commercial use, distribution, and reproduction in any medium, provided the original work is properly cited.

\begin{abstract}
In this study outcomes of arthroscopic management of tibial eminence fracture have been described. We conducted a study of 15 patients of ACL avulsion fractures especially Meyer and Mckeever type II and III treated arthroscopically by pull through sutures. Outcome measures were assessed through International Knee Documentation Committee (IKDC) form, Tenger Activity scale and Lysholm knee score. The study group consisted of 15 patients who met the inclusion criteria, of which 9 were male and 6 were female. The range of patient age consisted of 13-37 years and the average patient age was 20.6 years. The average male age was 22.11 years and the average female age was 18.33 years. The fracture classification showed 7 being type II while 8 were type III. Tegner Activity level at follow up ranged from 5-8 and the mean score was 6.4. On follow-up evaluation, the mean Lysholm score was 92.8 (ranging from 76-100). 6 patients who had inter-meniscal interposition was retracted or resected showed no difference in functional outcome. We found that displaced tibial eminence fractures could be successfully treated using arthroscopic pull through sutures, with most patients returning to their previous activity level. Complications were avoided by anatomic reduction of fracture fragments and early post-operative rehabilitation.
\end{abstract}

Keywords: Tibial eminence fracture, Arthroscopic technique, Pull-through sutures, Outcomes

\section{INTRODUCTION}

Tibial eminence fractures typically occur at bony insertion of the anterior cruciate ligament on the tibia. The incidence of these injuries in children is reported to around 3 per 100000 population per year. ${ }^{1}$ This is due to relative weakness of an incompletely ossified tibial eminence which is biomechanically weaker than native ACL fibres. ${ }^{2}$ Avulsion fracture of ACL results from sports where hyperextension with valgus or rotational force (skiing, football) and in high velocity trauma by motor vehicle accidents. $^{3}$

Most common features of these injuries are hemarthrosis, restricted and painful range of motion. ${ }^{4}$ Late diagnosis and inadequate treatment of acute injury may initiate rapid degenerative processes in the joint and cause a significant decrement in function of the patient. The arthroscopic intervention has replaced the open arthrotomy technique which was done earlier. ${ }^{5}$

\section{CASE SERIES}

A prospective case series was performed in 15 cases with tibial spine avulsion fracture. Between June 2019 to September 2020 in an orthopaedic tertiary care centre, all patient were operated by a single team of surgeon specialized in arthroscopic surgeries. All 15 patients included in series were managed by arthroscopic pull through suture technique. Various parameters were analyzed ranging from clinical symptoms, demographic data, mechanism of injury, pre- and post-op functional parameters and radiographic assessment through regular follow-up as mentioned in table no 1,2 and 3. 


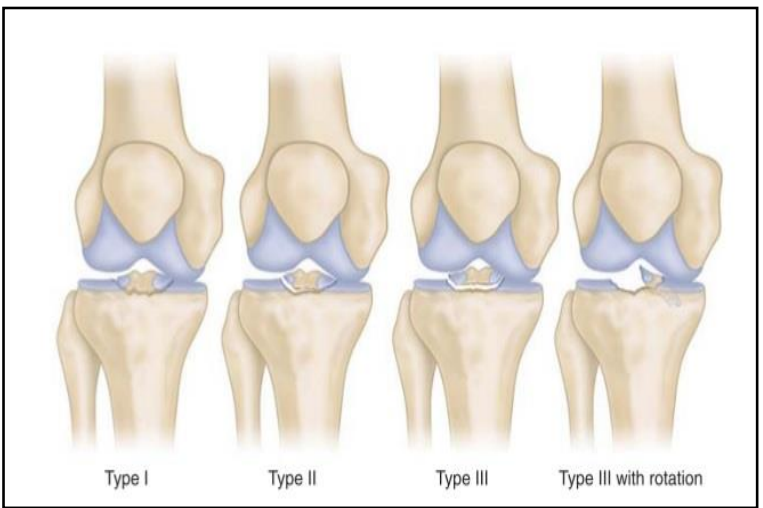

Figure 1: Modified Meyers and McKeever system.

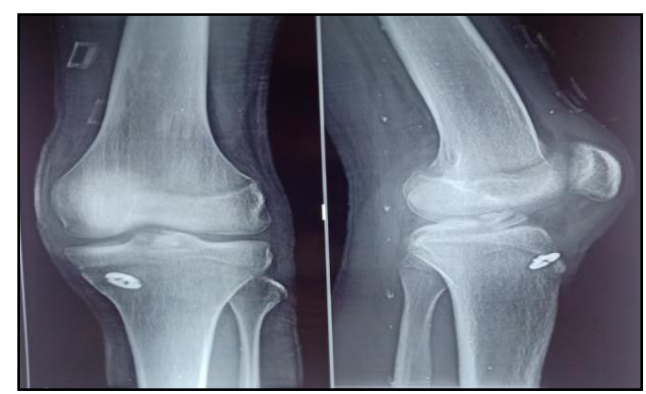

Figure 2: Radiograph post-surgery.

Table 1: IKDC activity level.

\begin{tabular}{|c|c|}
\hline Description of activity & $\begin{array}{ll}\text { Pre- } & \text { At } \\
\text { injury } & \text { follow-up }\end{array}$ \\
\hline $\begin{array}{l}\text { 1. Strenuous activity: } \\
\text { Jumping, pivoting, hard } \\
\text { cutting, football, soccer }\end{array}$ & \\
\hline $\begin{array}{l}\text { 2. Moderate activity: heavy } \\
\text { manual work, Skiing, } \\
\text { Tennis }\end{array}$ & \\
\hline $\begin{array}{l}\text { 3. Light Activity: light } \\
\text { manual work, jogging, } \\
\text { running }\end{array}$ & \\
\hline $\begin{array}{l}\text { 4. Sedentary Activity: } \\
\text { house work, activities of } \\
\text { daily living }\end{array}$ & \\
\hline
\end{tabular}

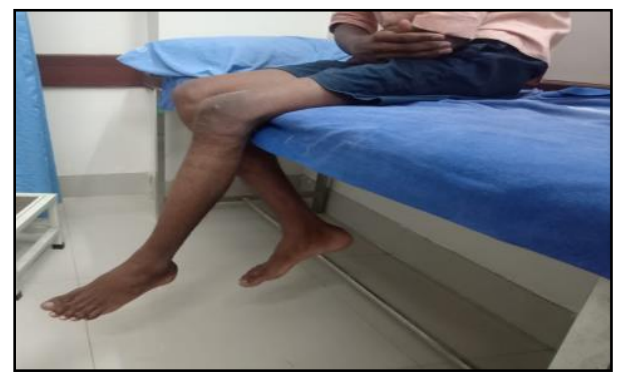

Figure 3: Flexion at 3 months post-surgery.

Clinically, inability to bear weight on affected limb, painful knee effusion. Range of movements is restricted and guarded, especially with respect to knee extension. It was found to be lax on performing anterior drawer test and lachman test. Radiograph used to assess the displacement and fracture pattern (AP and Lateral). The CT is better in evaluating the fracture but there is risk of radiation exposure in pediatric age group. MRI helps to determine the presence of concomitant injuries, displacement and communition.

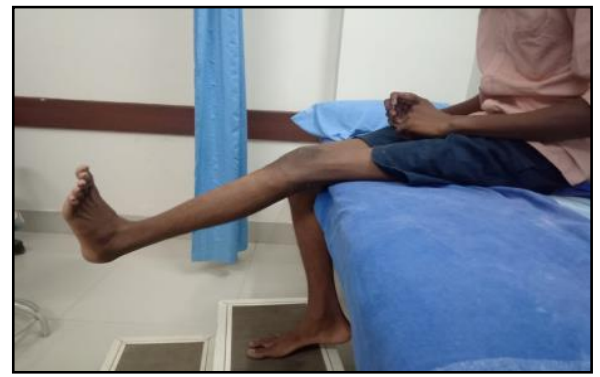

Figure 4: Extension at 3 months post-surgery.

Patients with age upto 50 years were included and classified as per Modified Meyers and McKeever system as mentioned in figure no 1. Patients with open injuries or any previous history of knee surgeries were excluded.

Tibial eminence fractures are most commonly classified according to the Modified Meyers and McKeever system.

Type I - Little or no displacement of the fragment.

Type II - fragment elevated anteriorly and proximally, with some displacement but with a cartilaginous hinge posteriorly.

Type III - completely displaced fracture with rotation.

Type IV - completely displaced, rotated, communited.

We have used arthroscopic approach for the treatment of tibial spine avulsion fractures. After placing patient in supine position diagnostic arthroscopy was performed to confirm and identify the other associated injuries. The standard arthroscopic portals are created. Soft tissues which prevent the reduction must be disengaged. If the intermeniscal ligament is trapped in the fracture it can be freed with the help of probe. Soft tissues shouldn't be removed unless until it is needed. Once cleared of soft tissues, the fracture bed and the undersurface of the avulsed tibial eminence should be debrided. With the help of ACL tibial jig tunnels were made from anteromedial aspect of fracture bed exiting just at the level of tuberosity. With the help of suture lasso2 PDS is passed around the base of ACL fragment and railroading of fibre tape was done. Base of the ACL fragment is strangulated with fibre tape in a crisscross manner with each end of the fibre tape passing through opposite tunnel. Reduction of the fragment was maintained with probe while tying the sutures. 
Table 2: Patient subjective assessment rating of the involved knee compared with the normal knee.

\begin{tabular}{|c|c|c|c|c|c|}
\hline Questions & Normal(a) & $\begin{array}{l}\text { Nearly } \\
\text { normal (b) }\end{array}$ & Abnormal @ & Severely abnormal (d) & $\begin{array}{l}\text { Group } \\
\text { grade a b c } \\
\text { d }\end{array}$ \\
\hline $\begin{array}{l}\text { 1. Function; } \\
\text { how does your } \\
\text { knee function } \\
\text { on a scale of } 0-3\end{array}$ & 0 & 1 & 2 & 3 & \\
\hline \multirow{2}{*}{$\begin{array}{l}\text { How does your } \\
\text { knee affect your } \\
\text { activity level }\end{array}$} & 0 & 1 & 2 & 3 & \\
\hline & $\begin{array}{l}\text { 1. Sternous } \\
\text { activity }\end{array}$ & $\begin{array}{l}2 . \\
\text { Moderate } \\
\text { activity }\end{array}$ & $\begin{array}{l}\text { 3. Light } \\
\text { activity }\end{array}$ & 4. Sedentary activity & \\
\hline \multicolumn{6}{|l|}{$\begin{array}{l}\text { 2. Symptoms; } \\
\text { grade at highest } \\
\text { activity level } \\
\text { with no } \\
\text { significant } \\
\text { symptoms }\end{array}$} \\
\hline \multicolumn{6}{|l|}{ Pain } \\
\hline \multicolumn{6}{|l|}{ Swelling } \\
\hline \multicolumn{6}{|l|}{$\begin{array}{l}\text { Partial giving } \\
\text { away }\end{array}$} \\
\hline \multicolumn{6}{|l|}{ Full giving away } \\
\hline Final evaluation & & & & & $\mathrm{A}, \mathrm{b}, \mathrm{c}, \mathrm{d}$ \\
\hline
\end{tabular}

Table 3: Demographic data and results.

\begin{tabular}{|c|c|c|c|c|c|c|c|c|c|c|c|c|c|c|c|}
\hline 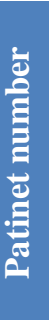 & $\frac{d}{0}$ & 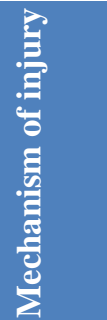 & 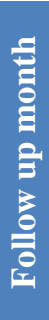 & 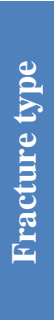 & 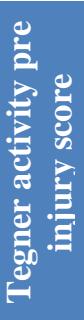 & 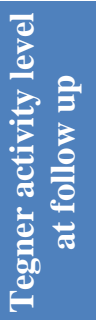 & 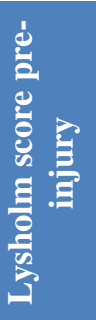 & 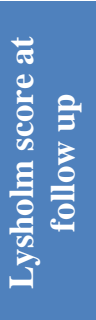 & 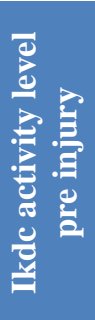 & 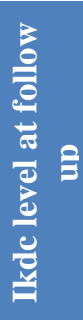 & 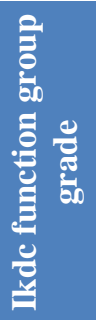 & 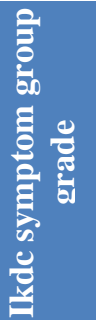 & 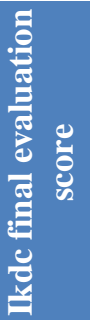 & 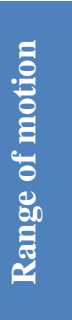 & 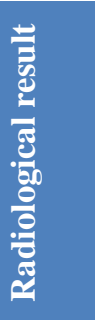 \\
\hline 1 & $16 / \mathrm{m}$ & Rta & 6 & Ii & 6 & 6 & 100 & 99 & 2 & 1 & A & A & A & $\begin{array}{c}0- \\
140\end{array}$ & $\begin{array}{l}\text { Unite } \\
\mathrm{d}\end{array}$ \\
\hline 2 & $14 / f$ & Rta & 6 & Iii & 6 & 6 & 100 & 99 & 2 & 2 & A & A & A & $\begin{array}{c}0- \\
135\end{array}$ & $\begin{array}{l}\text { Unite } \\
\mathrm{d}\end{array}$ \\
\hline 3 & $15 / \mathrm{m}$ & $\begin{array}{c}\text { Selffa } \\
\quad 11\end{array}$ & 6 & Ii & 7 & 7 & 100 & 100 & 2 & 1 & A & A & A & $\begin{array}{c}0- \\
140\end{array}$ & $\begin{array}{c}\text { Unite } \\
\mathrm{d}\end{array}$ \\
\hline 4 & $16 / \mathrm{m}$ & $\begin{array}{c}\text { Selffa } \\
\quad 11\end{array}$ & 6 & Ii & 6 & 6 & 100 & 90 & 2 & 2 & A & A & A & $\begin{array}{c}0- \\
130\end{array}$ & $\begin{array}{c}\text { Unite } \\
\mathrm{d}\end{array}$ \\
\hline 5 & $13 / f$ & Sports & 6 & Ii & 7 & 7 & 100 & 95 & 2 & 1 & A & A & A & $\begin{array}{c}0- \\
135\end{array}$ & $\begin{array}{l}\text { Unite } \\
\mathrm{d}\end{array}$ \\
\hline 6 & $13 / \mathrm{m}$ & Rta & 6 & Iii & 8 & 8 & 100 & 100 & 1 & 2 & A & A & A & $\begin{array}{c}0- \\
140\end{array}$ & $\begin{array}{l}\text { Unite } \\
\mathrm{d}\end{array}$ \\
\hline 7 & $14 / f$ & $\begin{array}{c}\text { Selffa } \\
\quad 11\end{array}$ & 6 & Ii & 6 & 5 & 100 & 84 & 2 & 2 & B & B & B & $\begin{array}{c}0- \\
130\end{array}$ & $\begin{array}{l}\text { Unite } \\
\mathrm{d}\end{array}$ \\
\hline 8 & $15 / \mathrm{m}$ & Sports & 6 & Ii & 9 & 9 & 100 & 95 & 1 & 2 & A & A & A & $\begin{array}{c}0- \\
130\end{array}$ & $\begin{array}{c}\text { Unite } \\
\mathrm{d}\end{array}$ \\
\hline 9 & $18 / \mathrm{f}$ & Sports & 6 & Iii & 6 & 7 & 100 & 100 & 2 & 2 & B & B & A & $\begin{array}{c}0- \\
140\end{array}$ & $\begin{array}{c}\text { Unite } \\
\mathrm{d}\end{array}$ \\
\hline
\end{tabular}




\begin{tabular}{|c|c|c|c|c|c|c|c|c|c|c|c|c|c|c|c|}
\hline 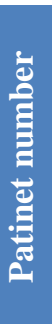 & $\frac{d}{d}$ & 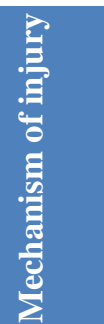 & 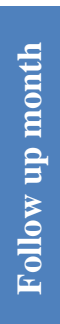 & 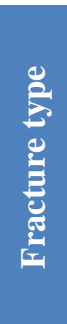 & 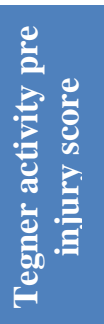 & 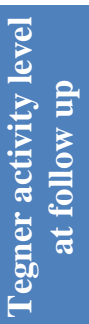 & 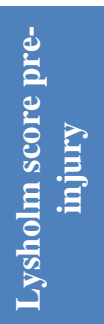 & 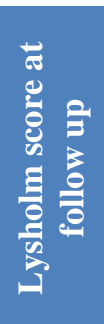 & 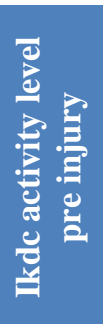 & 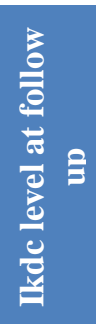 & 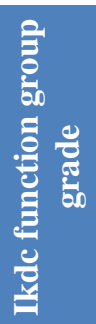 & 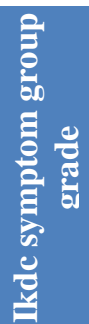 & 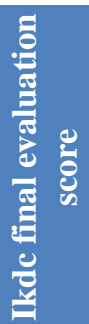 & 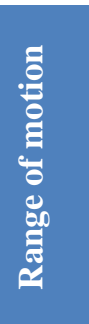 & 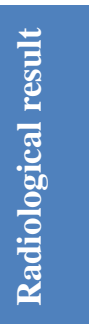 \\
\hline 10 & $22 / f$ & Rta & 6 & Iii & 6 & 5 & 100 & 90 & 2 & 3 & B & B & B & $\begin{array}{c}0- \\
130\end{array}$ & $\begin{array}{l}\text { Unite } \\
\text { d }\end{array}$ \\
\hline 11 & $24 / \mathrm{m}$ & Sports & 6 & Iii & 7 & 7 & 100 & 95 & 2 & 2 & B & B & B & $\begin{array}{c}0- \\
135\end{array}$ & $\begin{array}{l}\text { Unite } \\
\mathrm{d}\end{array}$ \\
\hline 12 & $28 / \mathrm{m}$ & Rta & 6 & Iii & 6 & 5 & 100 & 84 & 2 & 3 & B & A & A & $\begin{array}{c}0- \\
125\end{array}$ & $\begin{array}{c}\text { Unite } \\
\mathrm{d}\end{array}$ \\
\hline 13 & $29 / \mathrm{f}$ & Rta & 6 & Ii & 6 & 6 & 100 & 76 & 2 & 2 & B & $\mathrm{C}$ & C & $\begin{array}{l}10- \\
120\end{array}$ & $\begin{array}{c}\text { Unite } \\
\mathrm{d}\end{array}$ \\
\hline 14 & $35 / \mathrm{m}$ & Rta & 6 & Iii & 6 & 6 & 100 & 95 & 2 & 2 & A & B & A & $\begin{array}{c}0- \\
135\end{array}$ & $\begin{array}{c}\text { Unite } \\
\mathrm{d}\end{array}$ \\
\hline \multirow[t]{2}{*}{15} & $37 / \mathrm{m}$ & Rta & 6 & Iii & 6 & 6 & 100 & 90 & 2 & 2 & B & A & B & $\begin{array}{c}0- \\
130\end{array}$ & $\begin{array}{c}\text { Unite } \\
\mathrm{d}\end{array}$ \\
\hline & & & & & $\begin{array}{c}6.5 \\
3\end{array}$ & 6.4 & & 92.8 & & & & & & & \\
\hline
\end{tabular}

Post operatively plain radiographs were obtained to assess the reduction fragment (Figure 2). The knee is immobilized in extension using a long knee brace for a period of 4-6 weeks. Range of motion started on postoperative day 1 along with closed chain hamstring and quadriceps strengthening exercises. Toe touch weight bearing started at 4 weeks and advanced to full weight bearing at 6 weeks. Jogging was allowed at 10weeks. All patients achieved bone union. No young patients had growth disturbance of the tibia. The ROM protocol is similar to that of ACL rehab protocol (Figure 3,4). Unrestricted activities are advised after adequate strength is regained.

\section{DISCUSSION}

The study group consisted of 15 patients that met the inclusion criteria of which 9 were male and 6 were female. The range of patient age consisted of 13-37 years and the average patient age was 20.6 years. The average male age was 22.11 years and the average female age was 18.33 years and all females were below 29 years.

Most common mechanism of injury was found to be road traffic accidents (8) of which males were more common (5); followed by sports injuries (4) and then self falls (3).

Routine radiographs were taken and showed the fracture classification as 7 being type II while 8 were type III. Type of fixation used for all fractures was suture.

All patients were satisfied with their outcomes and no complications were reported on follow-up. The results are summarized in table no 3. The Tegner Activity level preinjury ranged from 6-9 and the mean score was found to be 6.53. Tegner Activity level at follow up ranged from 58 and the mean score was 6.4. Average Lysholm score preinjury was 100 . On follow-up evaluation, the mean Lysholm score was 92.8 (ranging from 76-100).

None of the patients had undergone subsequent surgery. Outcome data were analyzed using various parameters.

Fracture of tibial eminence are infrequently seen in general population which is about 2 to $5 \% .{ }^{6}$ Age played a role in patient outcome. Coyle et al conducted a systematic review which showed that with stress, the incompletely ossified tibial eminence in the children and adolescents fail before the ligament through the cancellous bone beneath the subchondral plate. ${ }^{7}$ Many studies emphasize the advantages of arthroscopic fixation techniques. A wide variety of fixation methods have been used to secure tibial eminence fractures, and as yet, there is no gold standard. Fixation with screws and fixation with sutures are among the most common methods and have yielded satisfactory results. ${ }^{8}$ Younger age groups showed no symptoms, normal knee function, and maintained pre-inury activity levels. No complaints of functional instability were seen at follow up evaluation. Intermeniscal interposition had no significant effect on follow up results. Even Najidi H et al in his retrospective studies on 24 patients revealed that intermeniscal interposition doesn't have any significant differences in outcome on long term basis. ${ }^{9}$ Range of motion in all patients were achieved by post op rehabilitation except one patient who required CPM exercises. Arthroscopic fixation yields positive outcome. Chad D Watts showed that there was increased incidence arthrofibrosis in patients treated by open reduction compared to that of those treated arthroscopically. ${ }^{10}$ Our study also showed that the complications are minimal in 
arthroscopic management and none of the patients developed arthrofibrosis. Complications like loss of motion, non-union, mal-union, impingement, growth disturbance and residual laxity can be managed by proper anatomical reduction and early post-operative mobilization. Fauno et. all evaluated transphyseal drilling in younger individual resulted in limb length discrepancies. ${ }^{11} \mathrm{We}$ avoided the complication by using all epiphyseal procedures whose growth was remaining.

\section{CONCLUSION}

We found that majority of tibial spine avulsion fractures can be successfully treated arthroscopically with pull through sutures. Suture fixation was suitable for type II, type III, and type IV fractures, as well as for communited fractures when screws and braces cannot be used. These patients have fast and predictable recoveries and are able to return to their pre-injury status. However, type of fixation, surgical versus nonsurgical treatment especially type II fractures remains a topic of debate.

Funding: No funding sources Conflict of interest: None declared

Ethical approval: Not required

\section{REFERENCES}

1. Aderinto J, Walmsley P, Keating JF. Fractures of the tibial spine: epidemiology and outcome. The Knee. 2008;15(3):164-7.

2. Tuca M, Bernal N, Luderowski E, Green DW. Tibial spine avulsion fractures: treatment update. Current opinion in pediatrics. 2019;31(1):103-11.

3. Strauss EJ, Kaplan DJ, Weinberg ME, Egol J, Jazrawi LM. Arthroscopic management of tibial spine avulsion fractures: principles and techniques. JAAOS-Journal of the American Academy of Orthopaedic Surgeons. 2018;26(10):360-7.
4. Gigante A, Setaro N, Rotini M, Finzi SS, Marinelli M. Intercondylar eminence fracture treated by resorbable magnesium screws osteosynthesis: a case series. Injury. 2018;49:S48-53.

5. Mclennan JG. The role of arthroscopic surgery in the treatment of fractures of the intercondylar eminence of the tibia. The Journal of bone and joint surgery. British volume. 1982;64(4):477-80.

6. Sawyer JR, Spence DD. Fractures And Dislocations in children.In :Frederick M.Azar,James,H.Beaty,S.Terry Canale (eds).Campbell'soperativeorthopaedics.13thed.Phila delphia: Elsevier . 1530-2.

7. Coyle C, Jagernauth S, Ramachandran M. Tibial eminence fractures in the paediatric population: a systematic review. Journal of children's orthopaedics. 2014;8(2):149-59.

8. Yuan Y, Huang X, Zhang Y, Wang Z. Treatment of tibial eminence fractures with arthroscopic suture fixation technique: a retrospective study. International journal of clinical and experimental medicine. 2015;8(8):13797.

9. Najdi H, Thévenin-Lemoine C, Accadbled F. Arthroscopic treatment of intercondylar eminence fractures with intraepiphyseal screws in children and adolescents. Orthopaedics \& Traumatology: Surgery \& Research. 2016;102(4):447-51.

10. Watts CD, Larson AN, Milbrandt TA. Open versus arthroscopic reduction for tibial eminence fracture fixation in children. Journal of Pediatric Orthopaedics. 2016;36(5):437-9.

11. Faun $\varnothing \mathrm{P}, \mathrm{R} \emptyset$ mer L, Nielsen T, Lind M. The risk of transphyseal drilling in skeletally immature patients with anterior cruciate ligament injury. Orthopaedic journal of sports medicine. 2016;4(9).

Cite this article as: Shreekantha $\mathrm{KS}$,

Gowthamapradhaban N, Malik D, Mahendranath. Arthroscopic management of tibial eminence fracture: a review of treatment outcome. Int J Res Orthop 2021;7:658-62. 